\title{
Parathyroid Hormone Therapy for Postoperative Resistant Hypocalcemia
}

\section{Introduction:}

No consensus guideline on the treatment of hypoparathyroidism.

Hypoparathyroidism is a disease characterized by hypocalcemia and insufficient PTH. Conventional therapy includes calcium and active vitamin D supplementation, often in large doses.

\section{Case Report:}

A 31 year-old woman presented with hypercalcemia. Serum calcium and phosphorus levels were $10.5 \mathrm{mg} / \mathrm{dl}$ and $2.56 \mathrm{mg} / \mathrm{dl}$, respectively. The serum PTH level was increased $(1619 \mathrm{pg} / \mathrm{ml})$. The serum $25 \mathrm{OH}$ vitamin $\mathrm{D}$ level was decreased $(3.5 \mathrm{ng} / \mathrm{ml})$. Her past medical history revealed osteoporosis (femur T score -4.0). Parathyroid USG showed left and right parathyroid adenomas. Double adenoma excision from left and right inferior sites and total thyroidectomy was performed. On pathological examination of thyroid was benign thyroid nodules. Double parathyroid adenomas was identified. Postoperative serum calcium level was $5.5 \mathrm{mg} / \mathrm{dl}$. She recieved daily calcium gluconate infusions. Discharge with calcitriol and $\mathrm{CaCO} 3$ with latest calcium level was $6 \mathrm{mg} / \mathrm{dl}$. During follow-up, she was taken to internal medicine ward with symtomatic hypocalcemia. Serum calcium, phosphorus, PTH, and $25 \mathrm{OH}$ vitamin D levels were $5.2 \mathrm{mg} / \mathrm{dl}, 3.2 \mathrm{mg} / \mathrm{dl},<3 \mathrm{pg} / \mathrm{ml}$, and $5 \mathrm{ng} / \mathrm{ml}$, respectively. The doses were progressively increased up to $12 \mathrm{mcg} / \mathrm{d}$ calcitriol. Under this tretatment serum calcium level was $6.9 \mathrm{mg} / \mathrm{dl}$. Phosphorus level was $3.8 \mathrm{mg} / \mathrm{dl}$. Follow-up, $20 \mathrm{mcg}$ teriparatide b.i.d was added to the treatment. She has used teriparatide for a period of ten months. At the end of teriparatide treatment, calcitriol reduced to $4.5 \mathrm{mcg} / \mathrm{d}$ and calcimax D3 reduced $3 \times 1 \mathrm{tb}$. Final control visit her calcium level was $8.5 \mathrm{mg} / \mathrm{dl}$ and phosphorus level was $4.1 \mathrm{mg} / \mathrm{dl}$ while taking calcitirol dose of $3.5 \mathrm{mcg} / \mathrm{d}$ and calcimax D3 dose of $2 \times 2 \mathrm{tb}$.

\section{Conclusion:}

In our postoperative hypocalcemic case, calcitriol dose reduced and calcium level increased after the teriparatide treatment. Teriparatide may be useful in postoperative resistant hypocalcemia. 